\title{
Buritish m
}

THE JOURNAL OF THE BRITISH MEDICAL ASSOCIATION

LONDON : SATURDAY, JANUARY 6th, 1934

\section{An Address \\ ov FOOD VALUES AND THEIR PRACTICAL
APPLICATION IN DIETETICS* BY \\ J. A. NIXON, C.M.G., M.D., F.R.C.P. PROFESSOR OF MEDICINE, UNIVERSITY OF BRISTOL}

Some knowledge of the physiological aspects of food values is essential to the planning of dietaries in health and disease. Popular views on dietetics have little or no foundation in physiological facts. In this paper I have endeavoured to gather together some of the essentials of food values that may prove helpful to the medical man in the discharge of his duties to the public.

The function of food is to provide heat and energy for the body; to repair worn-out tissues, and, during the years of growth, to build new tissues. To do this work the following are required: (1) water; (2) salts; (3) nitrogenous or protein matter; (4) non-nitrogenous matter, (a) carbohydrates-that is, starches and sugars, (b) fats ; and (5) vitamins.

Water is the body's greatest need. Man can survive deprivation of food for several weeks, but he can survive deprivation of water for a few days only (sixty to seventytwo hours). We take from 15 to $25 \mathrm{oz}$. of water in the solid food consumed, and beyond this some 2 to 4 pints as fluid. To get the maximum nutrition out of the solid food water should be taken in small quantitites at frequent intervals during a meal. It has been proved by experiments in man and animals that a reasonable dilution of solid food in the stomach makes the food go further. A dietary which, taken without water, will not suffice to maintain the balançe of intake and output can be made to do so by adding water to the meals.

The mineral elements of food have three chief functions. They contribute overwhelmingly to the structure of bone, and they assist in the formation of many organic compounds, such as nucleo-proteins and phosphatids, thus forming an integral part of every cell in the body. Civilized man runs the risk of not securing from his food all the needed mineral elements. The peel of fruit and the hull of cereal grains are often thrown away, such foods being thus robbed of important substances, notably iron, calcium, and phosphorus. In the process of cooking a good deal of mineral matter goes into solution and is thrown away. Some mineral elements are held in firm union with an organic component of the food, as, for example, cellulose, and until this indigestible substance

* Read to the East Somerset Division of the British Medical Association. is split up by intestinal bacteria or otherwise it cannot be taken up by the body. Dilution of cow's milk to reduce the protein content to that of human milk may dangerously reduce the calcium content of infants' food.

The following elements are present in the ash of animal tissues: iron, sodium, potassium, magnesium, calcium, phosphorus, sulphur, chlorine, iodine, fluorine, lithium, barium, manganese, aluminium, copp $=r$, and silicon. Some of these are needed in such small quantities that a sufficient supply is assured by almost any diet; others are needed in such large amounts that the diet often fails to furnish a sufficiency ; especially is this the case with iron, calcium, and phosphorus. Iron is needed for the haemoglobin of the red blood corpuscles. It is found in red, yellow, and green foods-that is, in red meats, fresh lean meat, especially in liver, which is valuable, perhaps, because of the copper as well as the iron content; in yolk of egg and carrots; and in vegetables and fruits and the hull of cereal grains. Food materials with little chlorophyll have little iron content. Milk-has a low iron content, but in readily assimilable form; fats, sugars. and starches contain little iron.

Calcium is needed for bones, for the clotting of blood, for normal action of the heart, in the physiology of nerve conduction, and for the energy exchange of muscle contraction. It is found primarily in milk; fruits and vegetables are relatively rich, while meat and milled cereals are poor in calcium. Phosphorus is needed for the nuclear construction of every cell, and is thus intimately concerned in all cell multiplication. It contributes largely to the bones, and the plasma and other fluids, being found in organic union with proteins, fats, and carbohydrates. It aids in the work of various glands, and can be found in their products, particularly in milk and the sexual elements. It is found abundantly in eggs and milk, alsc in wheat (entire grain, but not white flour), oatmeal, dried beans, and many nuts. A growing animal can, however, fully supply its mineral requirements from inorganic sources; it is therefore unnecessary to consider the calcium, phosphorus, and iron content in natural foods to the degree currently believed.

\section{PROTEINS}

Proteins vary in their value for growth and repair; they may therefore be classified according to their biological value. Proteins of animal origin, such as are found in meat, eggs, milk, fish, and cheese, are of high biological value (first-class); vegetable proteins are of low biological value (second-class)... The Royal Society Food (War) Committee suggested that the normal diet of an average man should consist of: protein 100 grams ; fat, 100 grams ; carbohydrate, 500 grams ; and calories, 3,390 . The $f$ oblem to be considered is how the 
necessary protein can most profitably and economically be provided. Some races have little or no choice in the matter. The Eskimos, for example, live entirely on animal food; they derive their protein and their fats from seal meat and blubber, or such other meat and fat as they may be able to obtain. Yet they live healthily, and are not liable to any special disease as the result of an entirely flesh diet; it is especially noteworthy that they do not develop arterial degeneration, kidney disease, or gout. They derive their calories partly from the fat and partly from the protein, of which 58 per cent. is convertible into glucose if needs be.

At the other end of the scale there are the West African tribes, who live on a diet of flour made from ripe bananas and on the bananas themselves. This one fruit can furnish every requisite, and, provided the bananas are ripe, they contain sufficient amino-acids to give the protein a good biological value. Infants in both these instances are suckled by their mothers; artificial feeding is not practicable. With the exception of this banana diet, no other vegetarian diet provides proteins of good enough biological value. It will be found that milk and eggs must be added. Casein of milk has the highest biological value; it supplies in full measure all the aminoacids essential to life. Growth and full vigour can be maintained on milk-the warriors of the Masai live on milk and blood. Meat comes next in order after milk, kidney ranking first, then liver, then muscle.

Although all the necessary amino-acids may be found in certain cereals, the amounts, in some instances, are inadequate. From the point of view of protein content, therefore, cereals must be supplemented, and it has been found that two cereals do not supplement each other. Milk is a cheaper source of protein than meat, and cheese is especially so. Those who can afford it (and many who cannot) prefer to take the larger part of their protein in meat and eggs, which cost more but are considerably tastier. Perhaps it is not, after all, an extravagance for the adult to prefer the costlier forms of protein. Meat and fish are more gratifying to the palate, and are definitely more satisfying. They may not be so filling at the time, but a meat meal seems to stay longer.

\section{Satiety Value}

This feature has been scientifically studied, and foods may actually be classified according to their satiety values, as well as their protein and calorie values. When the stomach and upper intestines contain food, and when normal muscular and secretory activities are at work, a feeling of satisfaction or satiety is experienced. Mere distension of the stomach is not enough to excite this feeling, and it is not experienced when the stomach is artificially distended. Slow passage through the intestine is as important as slow passage through the stomach, and the two go together, because foods that remain longest in the stomach call for the greatest secretion of hydrochloric acid. Two factors are taken as the measure of satiety value: (a) the length of time the food remains in the stomach, and $(b)$ the amount of gastric juice stimulated by the food. The accompanying tables are based on observations made in dogs by means of duodenal fistula.

\begin{tabular}{|c|c|c|c|c|c|c|c|}
\hline \multirow{2}{*}{\multicolumn{2}{|c|}{ Time in Stomach. }} & & & \multicolumn{4}{|c|}{ Amount of Sccretion. } \\
\hline & & & & Meat, 100 grams & $\ldots$ & & \\
\hline igg, har & & $\ldots$ & $2 \frac{1}{2}$ & & ... & $\ldots$ & 536 \\
\hline$"$ soft-boiled... & ... & $\ldots$ & $1 \frac{1}{2}$ & cm. & & $\cdots$ & \\
\hline & $\ldots$ & ... & $1 \frac{1}{6}$ & Milk, 2 ro c.cm. & $\ddot{\cdots}$ & $\cdots$ & 84 \\
\hline read, 200 grams & $\ldots$ & ... & $2 \frac{1}{2}$ & is $\cdots$ & $\cdots$ & $\cdots$ & \\
\hline Potatoes, $2 \mathrm{CO}$ grams & ... & ... & $3-4$ & $\ldots 00$ grams ... & $\cdots$ & $\cdots$ & 1 \\
\hline est $I$ & & & & 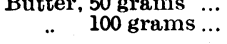 & $\cdots$ & $\cdots$ & \\
\hline $\begin{array}{l}\text { Soun, } \\
\text { Ditto, }\end{array}$ & & $\begin{array}{l}\ldots \\
\ldots\end{array}$ & $\begin{array}{l}3 \frac{1}{2} \\
8\end{array}$ & $\begin{array}{l}\text { Yet } b \\
\text { inc }\end{array}$ & & $a d$ & \\
\hline
\end{tabular}

It will be seen that the amount of sccretion is not always directly proportional to the amount of a food eaten. It is in the case of meat, but not in the case of bread, potatoes, or butter. So that the great importance of meat lies not only in its value as building and repair material and as fuel, but also in its ability to stimulate the stomach to great physiological activity. Meat and milk stand high, so do eggs, provided they are cooked sufficiently: cooked eggs are not only more easily digested than raw, but they have a greater satiety value. Bread and potatoes rank low if eaten by themselves, but when combined with either meat or fat (as in bread-and. butter) their satiety value is enhanced. Green vegetables, either alone or in combination with meat, have little satiety value. Sugar adds to satiety value in a marked degree. A meal containing something sweet remains longest in the stomach, and thus has the greatest satiety value. Coarse, indigestible foods, roughage in general, not only have no satiety value-they pass rapidly through the stomach-but they lead to subnormal digestion, and, therefore, to a poorer utilization of the contained protein. The popular laxatives, liquid paraffin and agar-agar, however beneficial they may be from a medicinal standpoint, retard digestion and carry away with them a certain amount of nutritive material. The amount of nutriment wasted may not be of great moment, because the majority of people in this country are not driven to support life on a minimal diet. Roughage is responsible in some people, however, for a good deal of vague abdominal discomfort, and even pain, so that appendicitis and colitis may be diagnosed. The discomfort disappears when the roughage is stopped.

\section{Quantitative Requirements}

Apart from the biological and the satiety value, the actual quantity of protein that is requisite must be considered. The earlier physiologists, Voit and Atwater, whc studied this protein problem, placed the proper intake for an average person at 118 and 120 grams respectively. Then Chittenden introduced the vogue of protein restriction, basing his observations on young, healthy, and enthusiastic young men who, during a brief period of their lives, suffered no harm on $\mathbf{4 0}$ to $\mathbf{5 0}$ grams daily. Chittenden's experiments have been most damagingly criticized by later workers, who have carried out extensive observations on animals, and by the world-wide involuntary experiences of the war. The conclusions of the Royal Socety's Food Committee may be accepted as being of far greater weight than Chittenden's. The committee laid down that 100 grams daily was the average requirement for physical and mental activity and for fertility, 50 grams of which should be "first-class" protein. High protein diets have been shown to have no harmful effects. Stefansson, the Arctic explorer, attributes the vigour and longevity of the Eskimos to the fact that their food is mostly meat, while he himself, when living for long periods among them and sharing their diet, enjoyed the highest degree of phys:cal and mental well-being. Thomas, who studied the exclusively carnivorous Eskimos of Labrador in the MacMillan expedition of 1926, came to the conclusion that their diet did not predispose them to renal or vascular disease.

A liberal protein intake has many advantages. 'A minimal intake may suffice for repairs and fuelling, but protein beyond those requirements exerts a specific dynamic action which has a stimulating effect upon vigour and general physiological efficiency ; it gives, in the words of McLester, " a boost to metabolism," a stimulus which contributes in no small degree to the vigour and virility of the individual and to the stamina of the race. We may get along for a time at least on a minimal protein 
intake, but a more generous intake ensures against decay and disease, and carries with it a liberal factor of safety.

\section{ENergy Value of Foods}

Besides growth and repair, food is required for the liberation of energy; the energy thus set free appears in the form of heat, mechanical work, and the activity of all the organs and structure of the body. Even the building up of the protein molecule so that it may be used for growth or repair demands the expenditure of energy. The energy contained in any foodstuff can be determined by the measurement of the heat which it yields on combustion in a calorimeter. It is expressed in calories or units of heat, one calorie being the amount of heat necessary to raise one kilogram of pure water from $15^{\circ} \mathrm{C}$. to $16^{\circ} \mathrm{C}$. For clinical purposes the following values are accepted: 1 gram of protein yields four calories, 1 gram of carbohydrate four calories, 1 gram of fat nine calories. The average working adult requires a diet containing some 3,400 calories, a female about 2,840 . For children the requirements are naturally less, but relatively to their weight and body surface their needs are higher than those of adults. A rough rule is that a boy of 14 requires the same calories as his father, and a girl of 14 the same as her mother. But the athletic schoolboy requires as much as 5,000 calories.

Proteins, carbohydrates, and fats can all supply the necessary heat and energy. But to utilize proteins for this purpose is, as a rule, economically wasteful: some part of the nitrogen of the protein is excreted by the kidney, proteins have greater specific dynamic action than carbohydrates and fats-that is, they speed up the metabolic processes of the body-and, finally, in this country, protein foods are the most expensive.

Carbohydrates. - These are the most rapidly utilized of all food materials. "They are the cheapest, and they reduce protein metabolism; they are " protein sparers." If carbohydrate is added to the diet the amount of meat required will be reduced. The most effective " proteinsparing " diet is a mixture of carbohydrates and fats in which at least half the energy is provided by the former. Wheat is the most economical foodstuff, because of its richness in carbohydrate and protein, the facility with which it can be stored and transported, and the ease with which it is prepared for table. But wheat reaches us in the form of flour-that is, when it is lacking in mineral and vitamin content, and its proteins are of low biological value. We eat it, therefore, chiefly for its carbohydrate content, which is at its highest in bread made of the finest white flour; economically the English are justified in their determination to eat white bread. Other grains are eatenrice, rye, barley, maize, and oatmeal ; their carbohydrate content is practically the same, but their palatability is considerably less. Breakfast cereals are very popular, but thoroughly wasteful and unnecessary. Many of them require cooking, and all of them are mere vehicles for the milk, cream, and sugar with which they are covered. Their own nutritive value is simply that of the grain from which they are prepared, and very often the extra price paid is merely to cover the cost of diminishing their food value by extracting some nutriment, which is sold in another market. Oatmeal (or porridge) is a food from which a relatively small proportion of its carbchydrate content can be assimilated. Sugar and sugary foods are valuable in so far as they are converted into glucose. Sugar offers in a concentrated form the most readily available carbohydrate, and it possesses a high satiety value. Unfortunately it has also disadvantages: it is easily eaten in excess, when it promotes obesity; in concentrated form it may irritate the gastric mucosa ; it is slow to leave the stomach, and may set up fermentation; and it may be the cause of a reduction in the consumption of other foodstuffs and lead to dietary deficiency.

Fats.-These have an important place in the diet. They yield twice as many calories as the same quantity of carbohydrate or protein ; without fats it is not easy to frame diets of the necessary calorie value. Fatty foods are believed to be indigestible, but much depends on their nature. Fats which melt at the temperature of the body are most easily assimilated, while those with a higher melting point are poorly utilized. In some people an excessive amount of fat will cause intestinal disturbances, and fat unbalanced by a sufficiency of glucose will give rise to ketosis and acidosis. Fatty food in suitable amount will, as we have seen, lead to retardation of the emptying time of the stomach, and thus add to the sense of comfort and satisfaction. Butter and cream present the most palatable and assimilable forms of fat. Fats are expensive, but indispensable; not only do they provide a high calorie yield in compact form, but they are the chief source of certain of the vitamins-namely, vitamins $\mathrm{A}$ and $\mathrm{D}$.

Vitamins.-An adequate diet must contain all the vitamins, although only minute quantities may be necessary. The average daily diet of adults in this country will contain all the sources of vitamins. For practical purposes a sufficiency of vitamin $A$ and $D$ is obtained from fats. For vitamin B we need not look to the germ of wheat as indispensable ; it is found abundantly in yolk of egg, in milk, in the leafy part of green vegetables, and in liver and kidney. It is not destroyed by the heat of ordinary cooking processes. P.P. or $B_{2}$ is found in similar foodstuffs, and is even more resistant to heat. Vitamin C-the anti-scurvy vitamin-is obtained from fresh fruit and vegetables, and from milk, provided the cow is not fed on oil-cake, but on fresh pasture or ensilage. Vitamin $E$ is found in nearly all our ordinary foodstuffs. For children it may sometimes be necessary to supplement the diet with artifically prepared vitamins, but for adults it will be far better for the housewife to take the advice of the British Medical Association Committee on Nutrition, and " spend money on good wholesome vitamin-containing foodstuffs, than to buy costly preparations of the concentrated vitamin-containing products." 1

Practical consideration of how to lay out a house-keeping allowance may be interesting. I have prepared a table showing the number of calories which can be bought with a shilling spent on different articles of food. It must be remembered that the purchases must include 100 grams of protein-fifty grams being " first-class "-a sufficiency of fat, and the fresh fruit and vegetables necessary to furnish vitamins and cellulose to give bulk to the faeces; some red meat is required for the sake of its iron. The fat must be balanced by the glucose in the protein and carbohydrate in the proportion of $\mathrm{F}=2 \mathrm{C}+\frac{1}{2} \mathrm{P}$ at least, otherwise acidosis and ketosis may result. One shilling will buy:

\begin{tabular}{|c|c|c|c|c|c|c|}
\hline & & & \multicolumn{3}{|c|}{ In Grams } & \multirow{2}{*}{$\underset{\text { Calories }}{\text { In }}$} \\
\hline & & & Protein & Fat & $\begin{array}{l}\text { Carbo- } \\
\text { hydrate }\end{array}$ & \\
\hline 11b. beef $\quad \ldots$ & $\cdots$ & $\ldots$ & 96 & 48 & - & $8 \div 0$. \\
\hline 5 pints milk ... & $\ldots$ & $\cdots$ & 100 & 100 & 150 & 1,900 \\
\hline $1 \frac{1}{4} 1 b$. cheese... & ... & $\ldots$ & 160 & 200 & 20 & 2,520 \\
\hline $12 \mathrm{oz}$. butter & $\cdots$ & $\cdots$ & - & 300 & - & 3,600 \\
\hline $81 \mathrm{~b}$. bread $\ldots$ & $\ldots$ & $\ldots$ & 384 & - & 2,048 & 9,728 \\
\hline $12 \mathrm{lb}$. potatoes & $\ldots$ & $\ldots$ & 192 & - & 1,344 & 6,144 \\
\hline
\end{tabular}


I conclude with an analysis of a day's meals, not perhaps such meals as we should take every day, but most of us can probably recall days when we have indulged to an equal extent.

\begin{tabular}{lcccc|c|c|c}
\hline Breakfast : & & & & & $\begin{array}{c}\text { Protein } \\
\text { (grams) }\end{array}$ & $\begin{array}{c}\text { Fat } \\
\text { (grams) }\end{array}$ & $\begin{array}{c}\text { Carbo- } \\
\text { hydrate } \\
\text { (grams) }\end{array}$ \\
\hline Tea or coffee & $\ldots$ & $\ldots$ & $\ldots$ & $\ldots$ & - & - & - \\
Milk, 5 oz. & $\ldots$ & $\ldots$ & $\ldots$ & $\ldots$ & 5 & 5 & 7.5 \\
Bread, 4 oz. & $\ldots$ & $\ldots$ & $\ldots$ & $\ldots$ & 24 & - & 67 \\
Butter, 1 oz. & $\ldots$ & $\ldots$ & $\ldots$ & $\ldots$ & - & 25 & - \\
Egg, one ... & $\ldots$ & $\ldots$ & $\ldots$ & $\ldots$ & 6 & 6 & - \\
Bacon, 2 oz. & $\ldots$ & $\ldots$ & $\ldots$ & $\ldots$ & 10 & 30 & - \\
Sugar, 1 oz. & $\ldots$ & $\ldots$ & $\ldots$ & $\ldots$ & - & - & 30 \\
Marmalade, 1 oz. & $\ldots$ & $\ldots$ & $\ldots$ & - & - & 25
\end{tabular}

LUNCH :

$$
\begin{array}{lllll|c|}
\text { Beefsteak, } 3 \text { oz.... } & \ldots & \ldots & \ldots & 24 \\
\text { Potato, } 2 \text { oz. } & \ldots & \ldots & \ldots & \ldots & 2 \\
\text { Onion, } 3 \text { oz. } & \ldots & \ldots & \ldots & \ldots & 1 \\
\text { Bread, } 2 \text { oz. } & \ldots & \ldots & \ldots & \ldots & 12 \\
\text { Butter, } 1 \text { oz. } & \ldots & \ldots & \ldots & \ldots & - \\
\text { Cheese, 1 oz. } & \ldots & \ldots & \ldots & \ldots & 8 \\
\text { Total calories, 1,055. } \\
\text { Half-pint of beer-Extra calcries, } 170 .
\end{array}
$$

\begin{tabular}{|c|c|c|c|c|c|c|}
\hline $\begin{array}{l}\text { Tea ... } \quad . . \\
\text { Milk, } 2 \text { oz }\end{array}$ & $\begin{array}{l}\cdots \\
\cdots\end{array}$ & $\begin{array}{l}\cdots \\
\cdots\end{array}$ & $\begin{array}{l}\cdots \\
\ldots\end{array}$ & $\cdots \mid$ & - & - \\
\hline Toast, 2 oz. & $\ldots$ & $\ldots$ & $\ldots$ & .. & 12 & - \\
\hline Butter, $\frac{1}{2} \mathrm{oz}$ & $\ldots$ & $\ldots$ & $\ldots$ & $\ldots$ & - & 12.5 \\
\hline Cake, $1 \mathrm{oz}$. & $\ldots$ & ... & $\ldots$ & $\ldots$ & 6 & 22 \\
\hline Sugar, 1 oz. & $\ldots$ & $\ldots$ & $\ldots$ & $\ldots 1$ & - & - \\
\hline
\end{tabular}

TeA :

DINNER :

\begin{tabular}{lcccc|c|c|c} 
Ovsters, half-dozen & $\ldots$ & $\ldots$ & $\ldots$ & 24 & 10 & 12 \\
Soup (clear), $4 \mathrm{oz}$. & $\ldots$ & $\ldots$ & $\ldots$ & 12 & - & 2 \\
Turbot, $3 \mathrm{oz}$. & $\ldots$ & $\ldots$ & $\ldots$ & $\ldots$ & 18 & 3 & 7 \\
Hollandaise sauce, 1 oz. & $\ldots$ & $\ldots$ & 1.4 & 1.3 & 0.25 \\
Roast beef, $4 \mathrm{oz}$. & $\ldots$ & $\ldots$ & $\ldots$ & 32 & 23 & - \\
Po:ato, $3 \mathrm{oz}$. & $\ldots$ & $\ldots$ & $\ldots$ & $\ldots$ & 3 & - & 18 \\
Cauliflower, 3 oz. & 1 & $\ldots$ & $\ldots$ & $\ldots$ & 1 & - & 5 \\
Apple tart, $4 \mathrm{oz}$. & $\ldots$ & $\ldots$ & $\ldots$ & 3.5 & 12 & 50 \\
Cream, 1 oz. & $\ldots$ & $\ldots$ & $\ldots$ & $\ldots$ & 1 & 6 & 1 \\
Orange, one & $\ldots$ & $\ldots$ & $\ldots$ & $\ldots$ & 1.5 & 0.25 & 25
\end{tabular}

Beverages : Tctal calories, 1,339.55.

\begin{tabular}{c|r}
15 & - \\
- & 12 \\
1 & 5 \\
- & 64 \\
25 & - \\
10 & 1
\end{tabular}

-
12
54
-
1

5 .

\section{THE “ACUTE EAR" IN GENERAL PRACTICE*}

\author{
BY
}

DOUGLAS GUTHRIE, M.D., F.R.C.S.

SURGEON TO THE EAR AND THROAT DEPARTMENT, ROYAL HOSPITAL FOR SICK CHILDREN, EDINBURGH

For years we have been accustomed to speak of the " acute abjomen," an expression which must recall to the mind of every practitioner recollections of the anxiety and heavy responsibility entailed in the conduct of any case of this nature. Certain emergencies connected with the ear are often as serious as those of the abdomen, and it would appear as though the more serious varieties of " acute ear" had been much in evidence during the past few months. Whether this is the result of a warm summer and consequent popularity of swimming pools it is cifficult to say. Certainly the percentage of severe ear infections has recently been greater, and in consequence the mortality of the " acute ear" higher. Any little contribution to our knowledge of the subject must therefore be of value, and must assist us to mitigate the fear which the word " mastoid" at present produces in the mind of the average layman.

\section{Causes and Clinical Course of Acute Middle-ear SUPPURATION}

Acute suppurative otitis is a disease of extreme frequency, especially in childhood. In the majority of cases the ear trouble is preceded by an ordinary head cold or tonsillitis, the infection passing from the nasopharynx to the tympanum by way of the Eustachian tube. It is a common complication of measles, and is also a common accompaniment of scarlet fever. The most frequent cause is a cold, the result of chill, and the organism most often found is the streptococcus. Infection by way of the external auditory meatus is relatively rare, and is usually the result of an accident, such as the penetration of a foreign body or a rupture of the membrane from an explosion or blow on the ear.

The following brief account of a typical case of acute otitis will illustrate the symptomatology.

A boy, aged 9, who had had a cold for a week, complained of sudden pain in one ear. This passed off in about ten minutes but returned a few hours later, and continued to return at brief intervals. When $I$ saw him the tympanic membrane was of deep red colour and slighty bulging near the centre. On incising the membrane there was a gush of thin sero-pus, and pain was at once relieved. The discharge was profuse for four days, and then gradually diminished. As usually happens, the deafness was the last symptom to disappear.

Pain in the ear is the leading symptom in most cases of acute otitis, and may, indeed, be the only symptom. In such circumstances it is well to remember the common causes of earache. A boil or furuncle in the meatus may cause earache, deafness, purulent discharge, and rise of temperature and pulse rate, and, if the meatal wall is swollen, diagnosis may only be possible after repeated observation. Other causes of earache are an unerupted wisdom tooth, a carious molar, arthritis of the temporomaxillary joint, tonsillitis, nasal sinus infection, and herpes auris. The mere recital of such causes illustrates the importance of complete examination in every case.

\section{Atypical Varieties of Acute Otitis Media}

A. Latent Otitis in Infants.-In small children there may be no symptoms pointing to an affection of the ear

* A B.M.A. Lecture delivered at Kirkcaldy to the Fife Branch of the British Medical Association on October 19th, 1933. 